\title{
ІНТЕРАКТИВНІ ТРЕНІНГИ НАВЧАННЯ ЖИТТСВИХ НАВИЧОК У ПОПЕРЕДЖЕННІ ВІЛ/СНІДУ СЕРЕД ШКОЛЯРІВ МІСТА
}

\author{
В. С. Василик, О. М. Крекотень
}

Вінницький національний медичний університет імені М. І. Пирогова

\section{INTERACTIVE LIFE SKILLS TRAINING TO PREVENT HIV-INFECTION AMONG SCHOOLCHILDREN OF THE CITY}

\author{
V.S. Vasylyk, O. M. Krekoten \\ Vinnytsia National Medical University by M. I. Pyrohov
}

\begin{abstract}
При опитуванні школярів 8-10 класів з питань поінформованості про ВІЛ-інфекцію виявлена суттєва різниця у школах, де проводились превентивні втручання.

In the survey of schoolchildren of 8-10 classes on issues of HIV-infection there was revealed a significant difference in schools where preventive interventions were performed.
\end{abstract}

Вступ. 3 часу виявлення першого випадку ВІЛінфекції у 1987 році і до 2010 року включно в Україні офіційно зареєстровано майже 182 тис. випадків ВІЛінфекції серед громадян України, у тому числі 37 тис. захворювань на СНІД та 21 тис. випадків смерті від нього [3].

Протягом 2010 року в країні зареєстровано 20,5 тис. нових випадків ВІЛ-інфекції (44,7 на 100 тис. населення). Завдяки реалізації комплексу заходів, спрямованих на призупинення епідемії ВІЛ-інфекції, зокрема серед споживачів ін'єкційних наркотиків (CIH), темпи приросту захворюваності на ВІЛ, починаючи з 2006 року, невпинно знижуються. Так, якщо в 2006 році, порівняно з попереднім 2005 роком, показник за- хворюваності на ВІЛ-інфекцію в цілому по країні збільшився на 16,8 \%, то в 2010 році, порівняно з 2009 роком, лише на $3,3 \%$ [3].

При аналізі домінуючих шляхів передачі ВІЛ було встановлено, що з 1995 до 2007 року основним шляхом передачі збудника був парентеральний, переважно при введенні наркотичних речовин ін'єкційним шляхом. В 2008 році відбулася зміна шляхів передачі ВІЛ - частка статевого шляху передачі стала вище парентерального при ін'єкціях наркотиків. У 2010 році продовжувалося зростання (до $45 \%$ ) частки осіб, які були інфіковані статевим шляхом, та зменшення питомої ваги інфікованих при введенні наркотичних речовин ін'єкційним шляхом - до 33,8 \% (рис. 1) [3].

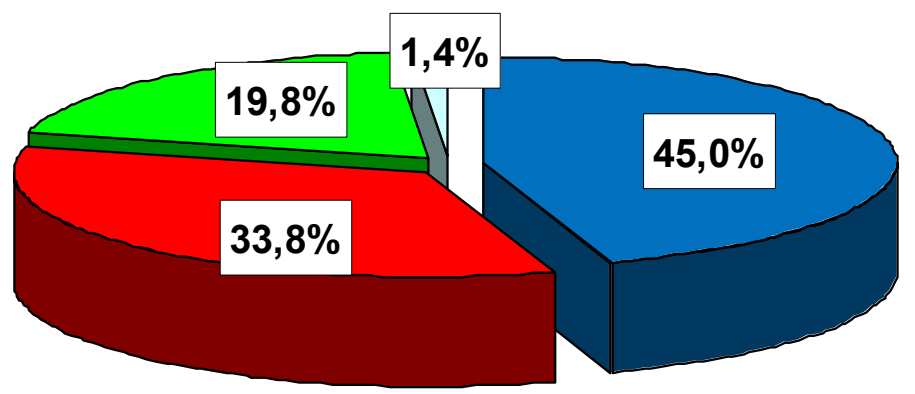

статевий

уведення наркотичних речовин ін'єкційним шляхом

кількість дітей, народжених ВІЛ-інфікованими матерями

не визначено

Puc. 1. Шляхи інфікування ВІЛ серед нових офіційно зареєстрованих випадків ВІЛ-інфекції у 2010 p.

(c) В. С. Василик, О. М. Крекотень 
Отже, статевий шлях стає більш домінуючим i особливо це загрозливо для молоді i, перш за все, підлітків, поведінка яких може бути ризиковою. Оцінка чисельності підлітків із числа груп ризику віком 10-19 років проводилась ГО "Український інститут соціальних досліджень імені Олександра Яременка" в рамках проекту ЮНІСЕФ “Профілактика ВІЛ серед підлітків груп ризику в Україні” у 2010 році і вона становить 85000 осіб (55 000 - хлопці, 30000 - дівчата) $[2,3]$.

Підлітки груп ризику - це діти та молоді люди, які внаслідок своєї поведінки найбільше наражаються на ризик інфікування ВІЛ, а саме: споживають ін'єкційні наркотики з використанням нестерильного ін'єкційного інструментарію; практикують незахищені статеві контакти внаслідок сексуальної експлуатації, включно з тими, хто став жертвою торгівлі людьми та мають незахищений (часто примусовий) секс за винагороду; хлопці, які мають незахищений анальний секс з чоловіками, в тому числі за винагороду. Пересічні підлітки внаслідок ситуативного ризику можуть стати жертвою інфікування.

Налагодити ситуацію 3 розповсюдженістю ВІЛ/ СНІДу саме серед цієї групи населення потребує проведення профілактичних заходів зміни ризикової поведінки молоддю.

В останні десятиріччя XX століття поняття “життєві навички” стало широко використовуватись у документах міжнародних організацій та інститутів для визначення концептуального підходу до забезпечення психосоціального розвитку дітей і профілактики соціально обумовлених захворювань (ВІЛ/ СНІД, ІПСШ, тютюнокуріння, алкоголізм, наркоманія) - Life skillsapproach. Даний підхід виник як альтернатива інформаційно-просвітницькому підходу, який показав свою неефективність у вирішенні зазначених завдань. Такий підхід брав за основу необхідність формування у дітей соціальних і поведінкових навичок, що дозволяли успішно вирішувати завдання інтеграції у суспільство, подолання життєвих труднощів, самозахисту від ризиків. Програми формування життєвих навичок передбачають активне використання інтерактивних методів навчання: моделювання ситуацій, рольові ігри, дискусії, мозковий штурм.

Хоча теоретичною основою підходу стали психологічні концепції, перш за все, біхевіоризм, соціальнокогнітивна теорія і теорія соціального впливу, в ньому передбачається відказ від складних психологічних інтерпретацій і робиться акцент на навчання людини. Формування життєвих навичок розглядається як необхідний компонент змісту освіти на сучасному етапі [2].
Найбільш відомою серед них можна вважати програму “Life - skills", розроблену Б. Спрангером i організацією Life-Skills International.

Освіта України тільки вступила в період засвоєння концептуальних уявлень про життєві навички, апробації закордонних програм і створення власних. Тому існує лише невелика кількість наукових публікацій ефективності роботи, методології таких програм, їх регіональне застосування $[1,2]$. Відчувається потреба у профілактичних програмах, згідно з якими вивчався б весь спектр чинників ризику і особливо поведінкових. Існуючі програми не виконують головної функції- формування стратегій поведінки, в рамках яких виробляється зв' язок мотиву, установки, навички як такої, чинника ризику, ситуації ризику.

Як показують результати проведених досліджень, всі працюючі в країні програми вносять свою частку. Найімовірніше, завдяки їм у підлітків та молоді існує система уявлень про чинники ризику для здоров'я, не виникає проблеми при необхідності відмовитися від пропозиції, принципово їм непридатної (але тільки в доброзичливій ситуаціi) [2]. Але сформованої соціальної позиції, направленої на збереження власного здоров’я і відмову від ризикової поведінки, немає.

Метою нашого дослідження було вивчення поінформованості з питань ВІЛ/СНІДу і вивчення особливостей статевої поведінки школярів різних шкіл. В одній школі міста проводились превентивні тренінги 3 навчання життєвих навичок за програмою "рівнийрівному” у рамках програми “Европейська мережа шкіл сприяння здоров’ю”, а у другій школі таких тренінгів не було (контрольна група).

Основна частина. Нами було здійснено соціологічне опитування стосовно поінформованості з питань ВІЛ/СНІДу серед школярів 8-10 класів міста Вінниці. Були задіяні 2 школи - в одній проводились тренінги навчання життєвих навичок за методом "рівнийрівному” у рамках програми “Европейська мережа шкіл сприяння здоров’ю”, а у другій не проводились. Загальна вибірка склала 400 по 200 осіб обох статей у кожній школі (100 хлопців і 100 дівчат). Використані методи: соціологічного опитування, експертної оцінки, статистичний. Обробка даних проводилась 3 використанням стандартних пакетів програм MicrosoftExcel, STATISTICA, використовуючи критерій Стьюдента. Був використаний опитувальник у рамках програми HBSC-““Здоров’я та поведінка молоді, що навчається”, модифікований автором.

У ході опитування виявлено, що у першій школі $95 \%$ правильних відповідей стосовно обізнаності ВІЛ/інфекції серед учнів 8-х класів, а у другій школі- 
лише $45 \%(\mathrm{p} \leq 0,05)$. Серед учнів 10 -х класів $97 \%$ правильних відповідей стосовно обізнаності ВІЛінфекції у школі, де проводились тренінги, i 67 \% правильних відповідей у школі, де не проводились тренінги ( $\mathrm{p} \geq 0,05)$.

Ми вивчали ризикову поведінку серед школярів стосовно ВІЛ/СНІДу - а саме статеві стосунки та їх захищеність. Отримали наступні результати при анонімному опитуванні у школі, де не проводились превентивні втручання: 21 \% учнів 10-го класу мали статеві стосунки (31\% хлопців і $13 \%$ дівчат $(\mathrm{p} \leq 0,05)$, $12 \%$ учнів 8-го класу (20\% хлопців і $3 \%$ дівчат $(\mathrm{p} \leq 0,05))$ за останні 30 днів. На питання “Чи користувалися Ви контрацептивами при статевому акті?" $16 \%$ хлопців і $2 \%$ дівчат, які навчаються у 8 класі, ( $\geq \geq 0,05)$ відповіли позитивно, а серед 10-х класів $29 \%$ хлопців і $10 \%$ дівчат відповіли позитивно $(\mathrm{p} \geq 0,05)$.

У школі, де проводились превентивні втручання, за останні 30 днів мали статеві стосунки $15 \%$ учнів 10 -го класу (34 \% хлопців і 8 \% дівчат $(\mathrm{p} \leq 0,05)), 10 \%$ учнів 8-го класу мали статеві стосунки (23\% хлопців і $2 \%$ дівчат $(\mathrm{p} \leq 0,05))$. На запитання "Чи користувалися Ви контрацептивами при статевому акті?” 20 \% хлопців і 2 \% дівчат, які навчаються у 8 класі, $(\mathrm{p} \leq 0,05)$ відповіли позитивно, а серед 10-х класів $20 \%$ хлопців i $6 \%$ дівчат $(\mathrm{p} \leq 0,05)$ відповіли позитивно.

Отже, наявний рівень знань учнів шкіл про ВІЛ/СНІД і ступінь поширення ризикованої щодо

\footnotetext{
Лiтература

1. Вступ до стратегічного планування для формування навичок здорового способу життя : посіб. / Проект ЄС "Вдосконалення багатогалузевих підходів до профілактики ВІЛ/СНІДу серед молоді України, Міністерство освіти та науки України”. -К., 2007. - 120 с.

2. Health behaviour in Schoo-aged Children: a World Health
}

інфікування поведінки не є адекватними загрозам нинішнього перебігу епідемічного процесу ВІЛ/СНІДу в Україні. За отриманими даними, хлопці раніше починають статеве життя і більш відповідальні або обізнані, а дівчата мають більш ризикову поведінку. Незалежно, чи проводились профілактичні заходи чи ні, початок статевого життя не змінюється і за останній період часу це відбувається все раніше. Заходи з контрацепції частіше проводять школярі тих шкіл, де профілактична робота все ж таки проводилась по навчанню методом "рівний-рівному” життєвих навичок протистояння тиску однолітків і попередження ВІЛ/СНІДу $(\mathrm{p} \geq 0,05)$.

Таким чином, навчальні заклади, де перебуває більшість молодих жителів України значну частину свого часу, можуть виступати вагомими засобами профілактики. Саме у школі 80-90 \% учнів отримують інформацію про ВІЛ/СНІД.

Висновки. Один 3 основних висновків - це необхідність створення комплексних проектів, у яких процес навчання був би підтриманий системою виховної роботи і діяльністю щодо організації дозвілля молоді. А глобальною прагматичною метою цих програм має стати скорочення числа курців, зменшення вживання алкоголю, наркотиків, більш пізній початок статевого життя, використання презервативів, зниження темпів розповсюдженості ВІЛ/ СНІДу.

Organization crossnational study (HBSC). Research Protocol for the 2005\2006 survey. Edinburgh, Child and Adolescent Health Research Unit, University of Edinburgh. - http:// www.hbsc.org.

3. ВІЛ-інфекція в Україні. Інформаційний бюлетень / [Н. М. Нізова та співавт.]. - К., 2011. -62 с. 